\title{
Intra-Island Industrial Incentives In Puerto Rico*
}

\author{
ROBERT S. WOODWARD\#
}

Governmental concern with the problem of unequal or limited regional economic opportunities has generated considerable interest in the relative effects of alternative public policies on the regional distribution of industrial activity. Within the limited framework of seeking to equalize regional employment and income levels, it is important to know which policies, especially which industrial incentives, can be expected to have the greatest effect on the distribution of manufacturing activity.

Examination of the Puerto Rican industrial incentives used to decentralize the island's manufacturing activity is valuable for several reasons. Most importantly, the intra-island incentives are apparently successful. Within the last decade, manufacturing employment has grown more rapidly outside than inside the metropolitan San Juan area, Table 1. This success contradicts Bridges' conclusion to a survey article on United States industrial subsidies, "Financial inducements of the types now in common use are certainly a secondary location factor in the choice of a region and are probably also a secondary factor in the choice of location within a region."

Second, specific conclusions about relative incentive strengths are useful for Puerto Ricans since decentralization continues to become a relatively more important policy objective and since the island's government continues to modify the intra-island incentives. Third, even though the Puerto Rican results may not be directly applicable to other countries, the approach used here (with some modi-

\section{TABLE 1}

\section{YEARLY GROWTH IN MANUFACTURING EMPLOYMENT}

\begin{tabular}{lccc} 
& $1956-60$ & $1960-65$ & $1965-69$ \\
\hline San Juan Metropolitan Area* & $6.2 \%$ & $3.8 \%$ & $5.0 \%$ \\
Rest of the Island & $0.4 \%$ & $9.5 \%$ & $6.5 \%$ \\
All Puerto Rico & $2.7 \%$ & $7.4 \%$ & $5.9 \%$ \\
\hline
\end{tabular}

Source: Estado Libre Asociado de Puerto Rico, Junta de Planificacion, “Indicadores Socio-Economicos (Años Seleccionados)," 1970.

*Includes the municipalities of Bayamon, Caguas, Carolina, Cataño, Guaynabo, Rio Piedras, San Juan and Trujillo Alto.

*This research was supported in part by a grant from the Puerto Rico Economic Development Administration. The author wishes to thank Charles Leven, David Felix, Juan Lopez Mangual, and Mark Frankena for their helpful comments. Remaining errors are the responsibility of the author.

\# The author is an Assistant Professor of Economics at the University of Western Ontario. 
fications required by differing data sources) is likely to be quickly and easily adoptable by most development bureaucracies.

The following sections review each of the specific industrial incentives designed to decentralize manufacturing locations. These include cash grants, or Special Incentives, which are offered to offset the extra initial capital and labor training costs of rural locations; rural industrial plant construction by the Puerto Rico Industrial Development Corporation (PRIDCO); lower PRIDCO rents in the rural zones; and additional years of corporate tax exemption for rural locations.

In order to define each of the intra-island incentives so that its impact on a firm's profit stream (or present value of that stream for alternative time horizons and discount rates) may be calculated, several assumptions are made. Perfectly competitive firms are assumed to maximize profits subject to a production function which uses inputs in fixed proportions with constant returns to scale. Also, inventories are assumed constant so that profit equals sales revenue minus direct and indirect costs.

\section{Special Incentives}

The Special Incentive grants were the first of the industrial incentives employed to decentralize manufacturing locations in Puerto Rico. From 1953, qualifying firms received these cash grants whose amount and payment terms depended on the firm's employment and fixed capital and on priority of the municipality for additional industrial activity. A short review of the ends and means of the Special Incentives during the sixties is presented below, followed by a discussion of the program's probable impact on profits.

During the early sixties, as the program's original goal of one plant in every municipality was almost achieved, it was evident that the economic growth of most rural municipalities continued to lag behind metropolitan San Juan. Thus in 1963 the Special Incentive program was reevaluated and new goals-a minimum of one job attributable to Economic Development Administration (EDA) promotion for each 100 inhabitants and an ultimate goal of one job for every 50 inhabitants-were formulated. These standards were interpreted to distinguish between four Special Incentive Zones-municipalities where there were (I) more than 100 persons per EDA job, (II) 50-100 persons per job, and (III) fewer than 50 persons per job. Zone IV included the municipalities experiencing industrial growth immediately surrounding San Juan. Further, the new policy designated employment, rather than fixed capital and employment, as the basic eligibility criterion, according to the schedule given in Table 2. Disbursements were to be made only if the firm's employment was over 30 by the third month or, where applicable, over 100 by the eighteenth month of commercial operations. An additional requirement was that at least $\$ 25,000$ investment, including at least $\$ 15,000$ in machinery and equipment, be completed before disbursements began.

In 1964 Zone I was subdivided into two zones and an emergency zone, E, was created, but little of the policy structure changed. Additional modifications in 1965 removed the grant limit as a percent of machinery and equipment for two zones, increased the payment per employee over thirty and relabeled the zones, Table 3. 
Although the policy statement for 1966 suggests a major review of the program goals, the actual incentive structure changed very little from the preceding year. The changes, presented in Table 4, modified eligibility criteria only. These 1966 incentives were available through 1970 .

The Special Incentive's impact on a typical firm's profits may be approximated by using information on the cash grant per employee and the present value of the profit stream per employee.

TABLE 2

SPECIAL INCENTIVES: April 1963

\begin{tabular}{lcccc}
\hline & \multicolumn{2}{c}{ Eligibility } & \multicolumn{2}{c}{ Disbursement Limitations } \\
\hline Zone & $\begin{array}{c}\text { Basic Incentive } \\
\text { for } 30 \text { Employees }\end{array}$ & $\begin{array}{c}\text { Additional } \\
\text { Per Employee }\end{array}$ & $\begin{array}{c}\text { Utilization } \\
\text { Period }\end{array}$ & $\begin{array}{c}\text { Max. Grant as a } \\
\text { of Mach. and Equi }\end{array}$ \\
\hline I & $\$ 30,000$ & $\$ 300$ & 2.5 years & $100 \%$ \\
II & $\$ 20,000$ & $\$ 200$ & 2.5 years & $100 \%$ \\
III & $\$ 15,000$ & $\$ 150$ & 2 years & $100 \%$ \\
IV & $\$ 5,000$ & $\$ 75$ & 2 years & $100 \%$ \\
\hline
\end{tabular}

TABLE 3

SPECIAL INCENTIVES: September 1965

\begin{tabular}{lccccc}
\hline & \multicolumn{2}{c}{ Eligibility } & & \multicolumn{2}{c}{ Disbursement Limitations } \\
\hline Zone & $\begin{array}{c}\text { Basic Incen- } \\
\text { tive for } 30 \\
\text { Employees }\end{array}$ & $\begin{array}{c}\text { Per Employee } \\
\text { Between }\end{array}$ & $\begin{array}{c}\text { Per Addit. } \\
\text { Employee }\end{array}$ & $\begin{array}{c}\text { Utility } \\
\text { period }\end{array}$ & $\begin{array}{c}\text { Max. Grant as } \\
\text { a } \% \text { of Mach. } \\
\text { and Equip. }\end{array}$ \\
\hline I & $\$ 30,000$ & $\$ 428$ & $\$ 400$ & 2.5 years & no limit \\
II & $\$ 20,000$ & $\$ 200$ & $\$ 200$ & 2.5 years & no limit \\
III & $\$ 15,000$ & $\$ 143$ & $\$ 150$ & 2 years & $100 \%$ \\
IV & $\$ 10,000$ & $\$ 100$ & $\$ 100$ & 2 years & $100 \%$ \\
V & $\$ 5,000$ & $\$ 71$ & $\$ 75$ & 2 years & $100 \%$ \\
\hline
\end{tabular}

TABLE 4

SPECIAL INCENTIVES: November 1966

\begin{tabular}{lccc}
\hline Zone & $\begin{array}{c}\text { Basic Incentive } \\
\text { for 30 Employees }\end{array}$ & $\begin{array}{c}\text { Per Employee Between } \\
30 \text { and } 100\end{array}$ & $\begin{array}{c}\text { Per Addit. } \\
\text { Employee }\end{array}$ \\
\hline I & $\$ 30,000$ & $\$ 430$ & $\$ 400$ \\
II & $\$ 20,000$ & $\$ 210$ & $\$ 190$ \\
III & $\$ 15,000$ & $\$ 150$ & $\$ 140$ \\
IV & $\$ 10,000$ & $\$ 105$ & $\$ 95$ \\
V & $\$ 7,000$ & $\$ 90$ & $\$ 75$ \\
\hline
\end{tabular}




$$
\begin{aligned}
& \% \text { change } \\
& \text { in profits }
\end{aligned}=\frac{\frac{\text { Special Incentives }}{\text { Employees }}}{\frac{\text { Present Value of Profits }}{\text { Employees }}} \times 100
$$

Using the 1963-64 average yearly profit per employee (approximately $\$ 2,800)^{2}$ for all firms receiving some form of incentive or assistance from EDA, the maximum Special Incentive grant of $\$ 1,000$ per employee is likely to have the profit impacts reported in Table 5.

TABLE 5

PERCENT CHANGE IN PROFITS CAUSED BY SPECIAL INCENTIVE GRANT OF $\$ 1,000$ PER EMPLOYEE

\begin{tabular}{crrrr}
\hline Firm's Years & \multicolumn{4}{c}{ Rate of Discount } \\
in Operation & $6 \%$ & $10 \%$ & $20 \%$ & $30 \%$ \\
\hline 4 & $10.3 \%$ & $11.3 \%$ & $13.8 \%$ & $16.5 \%$ \\
8 & $5.8 \%$ & $6.7 \%$ & $9.3 \%$ & $12.2 \%$ \\
12 & $4.3 \%$ & $5.2 \%$ & $8.0 \%$ & $11.2 \%$ \\
17 & $3.4 \%$ & $4.5 \%$ & $7.5 \%$ & $10.8 \%$ \\
\hline
\end{tabular}

\section{PRIDCO Plants}

PRIDCO's construction and EDA's promotion of standard 11,500 and 23,000 square foot industrial plants built in anticipation of demand have increasingly become a means of attracting industry to the island's rural municipalities, Table 6 . By locating in these buildings, a firm is likely to reduce the delay in starting production as well as its search costs and risks from long term investments in fixed plants. Since there are always 20-50 buildings available for immediate occupation, a firm can reduce its lost returns from production delayed by the search and rental negotiations for a privately owned plant site. Since EDA has promotional officers in the United States who facilitate the flow of information about available

\section{TABLE 6}

\section{PRIDCO CONSTRUCTION IN THE SAN JUAN METROPOLITAN} AREA AND THE REST OF THE ISLAND (Thousands of Square Feet)

\begin{tabular}{lcc} 
Period & $\begin{array}{c}\text { San Juan } \\
\text { Metropolitan } \\
\text { Area }\end{array}$ & $\begin{array}{c}\text { Rest of } \\
\text { the Island }\end{array}$ \\
\hline $1955-59$ & 1205 & 1712 \\
$1960-64$ & 1013 & 2985 \\
$1965-69$ & 990 & 5420 \\
\hline
\end{tabular}


plant sites, a firm's executive time required to make a location decision is reduced. Finally, since the buildings are usually rented, PRIDCO construction allows riskaverting firms to avoid committing their long-term funds to plant construction. Although the cost of executive time and the dollar value of risk averted by renting a plant may be significant, the foregone returns from delayed production are judged to be the most important and the only quantifiable of the three cost reductions attributable to PRIDCO construction.

The profit impact of the foregone returns is first calculated under the assumptions that the opportunity cost of capital is zero and that the firm has a complete tax exemption for the investment horizon.

$$
\mathrm{V}=\frac{\left(\mathrm{V}_{1}-\mathrm{V}_{0}\right) 100}{\mathrm{~V}_{0}}
$$

where $\mathrm{V}=$ the percentage increase in the present value of profits

$$
\begin{aligned}
& V_{o}=R \int^{b} e^{-r t} d t \\
& a_{1} \quad 0<a_{1}<b \\
& \mathrm{~V}_{1}=\mathrm{R} \int_{0}^{\mathrm{b}} \mathrm{e}^{-\mathrm{rt}} \mathrm{dt} \\
& a_{1}=\text { search time } \\
& \mathrm{b}=\text { investment horizon } \\
& \mathrm{R}=\text { annual stream of profits }
\end{aligned}
$$

If these assumptions are maintained and if four to eight months is a reasonable expected search time for a privately constructed plant, the percent increase in the present value of profits affected by the availability of PRIDCO plants, is substantial, Table 7.

Inclusion of capital's opportunity cost, which may be the rate of return on short-term portfolio investments, decreases the search costs $\left(\mathrm{V}_{1}-\mathrm{V}_{0}\right)$ by the fraction of profits which opportunity costs represent. Thus, the profit impact of PRIDCO plant availabilities is decreased. For example, as capital's opportunity cost approaches the expected investment return, the search cost approaches zero. More realistically, if the expected investment return is $24 \%$, the 1963-64 average return to equity for all EDA manufacturing plants, ${ }^{3}$ and opportunity costs are $10 \%$, the percent increase in profits present value calculated in Table 7 would necessarily be deflated by $42 \%$. Since information needed for calculating the exact difference between the expected profit rate and the short-term portfolio rate 
TABLE 7

A

The Percent Increase in the Present Value of Profits From Being Able to Start Operations 4 Months Earlier in a PRIDCO Plant

\begin{tabular}{crrrr}
\hline Years & \multicolumn{4}{c}{ Interest Rate } \\
Operating & \multicolumn{1}{c}{ 6 } & 10 & 20 & 30 \\
\hline 4 & 10.2 & 11.0 & 13.3 & 15.8 \\
8 & 5.5 & 6.3 & 8.8 & 11.7 \\
12 & 4.0 & 4.9 & 7.6 & 10.8 \\
17 & 3.2 & 4.2 & 7.1 & 10.6 \\
\hline
\end{tabular}

\section{B}

The Percent Increase in the Present Value of Profits from Being Able to Start Operations 8 Months Earlier in a PRIDCO Plant

\begin{tabular}{crrrr}
\hline Years & \multicolumn{4}{c}{ Interest Rate } \\
Operating & 6 & 10 & 20 & 30 \\
\hline 4 & 22.5 & 24.3 & 29.3 & 35.0 \\
8 & 11.5 & 13.3 & 18.5 & 24.9 \\
12 & 8.3 & 10.2 & 15.9 & 22.9 \\
17 & 6.5 & 8.6 & 14.8 & 22.3 \\
\hline
\end{tabular}

is not available, more reliable deflation is impossible. Importantly, even after a $42 \%$ deflation, PRIDCO construction seems likely to significantly affect profits.

\section{PRIDCO Rents}

The PRIDCO rental rate per square foot depends upon the rental zone in which each plant's municipality is located. Although slightly higher for buildings under 11,000 square feet, rents for standard buildings, Figure 1, have ranged from the $1954 \$ .70$ and $\$ .40$ per square foot to the current $\$ 1.20$ and $\$ .75$ per square foot in San Juan and the most rural municipalities, respectively.

Since substitutability among production inputs is assumed to be zero, the profit impact of a rural (or urban) rental subsidy would be determined by (1) dollars per square foot of subsidy, (2) dollars of sales per square foot, and (3) profits as a percent of sales according to the following formula:

$$
\begin{gathered}
\% \text { change in } \\
\text { profits }
\end{gathered}=\frac{\frac{\text { subsidy }}{\text { square feet }}}{\frac{\text { sales }}{\text { square feet }} \times \frac{\text { profits }}{\text { sales }}} \times 100
$$




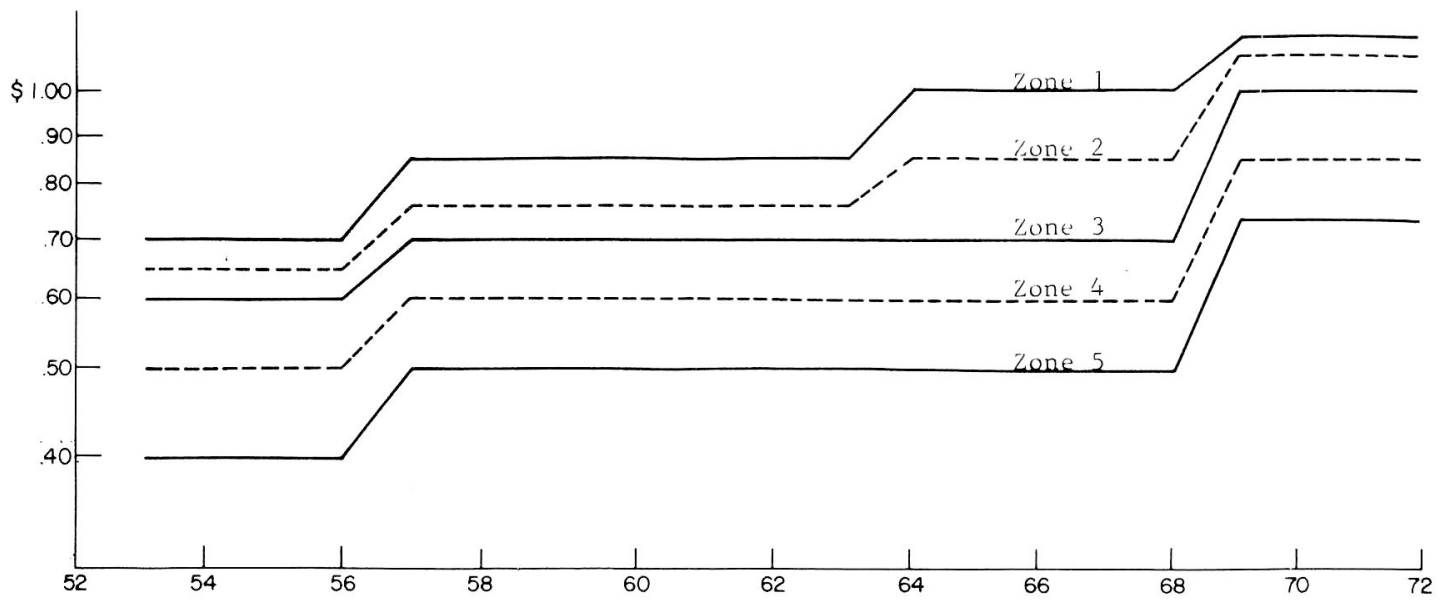

Figure 1

Annual PRIDCO Rents per Square Foot Standard Buildings

The value per square foot of PRIDCO rental subsidy would be determined by analyzing the difference between private and PRIDCO rents for equivalent buildings in the same region. Since data on market rental rates are not available at any level of regional aggregation, direct determination of subsidy size is impossible.

Nevertheless, it is possible to predict the importance of any of the rent changes according to the formula:

$$
\underset{\text { profits }}{\text { change in }}=\frac{\text { rent change }}{\frac{\text { sales }}{\text { square feet }} \times \frac{\text { profits }}{\text { sales }}} \times 100
$$

Estimates of $\$ 50$ to $\$ 70$ sales per square foot per year were derived from information on sales and on PRIDCO plant size for EDA assisted firms in five selected industries. Using the $\$ 60$ average and a profit-sales ratio of $16 / 100,{ }^{4}$ the $1964 \$ .10$ rent increase in the San Juan metropolitan area lowered profits by approximately $1 \%$. Neither that intra-regional change nor the $1969 \$ .25$ rent increase for all municipalities is likely to have significantly lowered profits.

\section{Tax Exemptions}

The island's unique relationship to the United States ${ }^{5}$ has allowed the Puerto Rican government to grant qualified United States corporations locating on the island a total tax holiday, including income taxes, property taxes and license fees. Since 1953 a corporation which produces goods not manufactured on the island on or before January 2, 1947, produces one of the articles designated as important to the economy, or produces for export to foreign countries has been eligible to receive at least 10 years exemption regardless of location. 
As part of the decentralization program, in 1961 the Puerto Rican government increased the period of corporate income tax exemption available in some rural municipalities from 10 to 13 years. In 1963, the years of exemption were again increased, except in the San Juan metropolitan area, from 13 (or in some cases 10) to 17 years in the most rural municipalities and from 10 to 12 years in the more heavily populated coastal municipalities.

Since a corporate income tax exemption is equivalent to a profit subsidy, it is possible to determine a longer exemption's impact on profits. Assuming constant prices and the firm's profit maximization goal, the importance of extra years of exemption may be examined by determining the extra years' impact on the present value of the profit stream over the expected profit horizon. Using Kenneth Kauffman's notation with slight modification, ${ }^{6}$ this section seeks to determine the percent increase in present value $(V)$ of the stream of annual profits $(R)$ and assumes that $R$ is constant over time. Where $V_{1}$ is the present value of the profit stream with the extra years of exemption and $V_{0}$ the present value of the stream without the extra years of exemption:

$$
\mathrm{V}=\frac{\mathrm{V}_{1}-\mathrm{V}_{\mathrm{o}}}{\mathrm{v}_{\mathrm{o}}} \cdot 100
$$

Using the notation for continuous time where

$\mathrm{r}=$ the rate of discount of future income

$\mathrm{w}=$ the tax rate in the absence of the exemption

$\mathrm{z}=$ the tax rate during the exemption $(\mathrm{z}=0$ in Puerto Rico)

$a_{0}=$ the original number of years of tax exemption

$a_{d}=$ the number of years of exemption after the increase

$\mathrm{b}=$ the investment horizon

$$
\begin{gathered}
\left.\mathrm{v}_{\mathrm{o}}=\mathrm{R} \quad(\mathrm{l}-\mathrm{z}) \int_{0}^{\mathrm{a}_{0}} \mathrm{e}^{-\mathrm{rt}} \mathrm{dt}+(\mathrm{l}-\mathrm{w}) \int_{\mathrm{a}_{\mathrm{o}}}^{\mathrm{b}} \mathrm{e}^{-\mathrm{rt}} \mathrm{dt}\right] \\
\mathrm{v}_{\mathrm{l}}=\mathrm{R}\left[(\mathrm{l}-\mathrm{z}) \int_{0}^{\mathrm{a}_{1}} \mathrm{e}^{-\mathrm{rt}} \mathrm{dt}+(\mathrm{l}-\mathrm{w}) \int_{\cdot \mathrm{a}_{1}}^{\mathrm{b}} \mathrm{e}^{-\mathrm{rt}} \mathrm{dt}\right]
\end{gathered}
$$




$$
V=\frac{(w-z)\left(e^{-a_{0} r}-e^{-a_{1} r}\right)}{\left(1-e^{-r b}\right)-z\left(1-e^{-a_{0} r}\right)-w\left(e^{-a_{0} r}-e^{-b r}\right)}
$$

where $\mathrm{z}=0$,

$$
V=\frac{w\left(e^{-a_{0} r}-e^{-a_{1} r}\right)}{\left(1-e^{-r b}\right)-w\left(e^{-a_{0} r}-e^{-r b}\right)}
$$

Calculations of the percent increase in the present value for various interest and tax rates and a seventeen-year income stream, presented in Table 8, indicate that the extra seven years are approximately two times more effective than the two years where the interest rate is high and three times as effective when the interest rate is low. The calculations also indicate considerable sensitivity to the Puerto Rican corporate tax rate, between $20 \%$ and $40 \%$, after the tax exemption ends.

It must be noted that the results depend upon the assumption of at least a seventeen-year income stream and equipment life. To the extent that capital life is shorter, the extra years will have less significance in the initial investment decision than suggested in the tables. Although statistics in the one available source "Bulletin F" are old, they indicate that assuming a seventeen-year equipment lifetime is reasonable. For example, they indicate that machinery used in producing electrical equipment has a composite life of 17-20 years, while machinery in spinning and weaving cotton, wool or silk has approximately a 25-year lifetime. Nevertheless, Kuh and Schmalensee more recently found average manufacturers' equipment and plant lifetimes to be 14.3 and 38.1 years, respectively. ${ }^{8}$

\section{Summary}

Since the impact of all three of the available intra-regional incentives depends upon the discount rate and the expected duration of the firm's income stream, ranking the importance of each of the incentives can only be accomplished for specific values of years and the discount rate, Table 9. Referring to the tabulated results, it is evident that the Special Incentives and PRIDCO construction have approximately the same profit impact under all conditions, and both are more valuable than the extra years of tax exemption for all firms but those with a long life and a low discount rate.

Further, it is valuable to note that these profit impacts have different sensitivities to some of their common determinants. Although larger discount rates reduce the profit impact of all three incentives, a firm's longer period of operations 
TABLE 8

Percent Increase in Present Value of Profits for Extra Years of Tax Exemption*

A. Two Years Added to Ten

\begin{tabular}{rcrc}
\hline $\begin{array}{c}\text { Interest } \\
\text { Rate }\end{array}$ & $20 \%$ & Tax Rate & \\
\hline $6 \%$ & $2.08 \%$ & $30 \%$ & $40 \%$ \\
$10 \%$ & $1.75 \%$ & $3.22 \%$ & $4.44 \%$ \\
$20 \%$ & $1.06 \%$ & $2.69 \%$ & $3.68 \%$ \\
$30 \%$ & $.61 \%$ & $1.61 \%$ & $2.17 \%$ \\
\hline
\end{tabular}

B. Three Years Added to Ten

\begin{tabular}{rcrc}
\hline Interest & \multicolumn{3}{c}{ Tax Rate } \\
Rate & $20 \%$ & $30 \%$ & $40 \%$ \\
\hline $6 \%$ & $3.03 \%$ & $4.69 \%$ & $6.47 \%$ \\
$10 \%$ & $2.51 \%$ & $3.86 \%$ & $5.28 \%$ \\
$20 \%$ & $1.46 \%$ & $2.22 \%$ & $3.00 \%$ \\
$30 \%$ & $.81 \%$ & $1.22 \%$ & $1.64 \%$ \\
\hline
\end{tabular}

C. Seven Years Added to Ten

\begin{tabular}{rcrr}
\hline $\begin{array}{c}\text { Interest } \\
\text { Rate }\end{array}$ & $20 \%$ & Tax Rate & \\
\hline $6 \%$ & $6.33 \%$ & $30 \%$ & $40 \%$ \\
$10 \%$ & $4.91 \%$ & $9.80 \%$ & $13.51 \%$ \\
$20 \%$ & $2.50 \%$ & $7.55 \%$ & $10.33 \%$ \\
$30 \%$ & $1.25 \%$ & $3.80 \%$ & $5.13 \%$ \\
\hline
\end{tabular}

*Income stream assumed to be seventeen years for all tables.

reduces the profit impact of the Special Incentives and PRIDGO construction and increases the impact of the extra years of tax exemption. Larger profits (given a firm with a long operational period and a fixed employment and plant size) reduce the profit impact of the Special Incentives and PRIDCO construction and increase the impact, both absolutely and in percentage terms, of the extra years of tax exemption. Overall, the intra-regional incentive program seems to slightly favor the firms with shorter operational expectations and higher discount rates. Nevertheless, the increased importance of the extra years of tax exemption does partially offset the diminished impact of Special Incentives and PRIDCO construction for firms with long lives and low discount rates.

In conclusion, it is important to note that the island government directly recovers some of its incentive outlays only in the case of PRIDCO construction where much of the $\$ 6.80$ to $\$ 8.80$ per square foot initial construction cost is likely 
TABLE 9

Percent Increase in Profits Caused by Puerto Rico's Industrial Incentives for Rural Locations

\begin{tabular}{|c|c|c|c|c|c|}
\hline \multicolumn{5}{|c|}{ Industrial Incentives } & \multirow[b]{2}{*}{ TOTAL } \\
\hline \multicolumn{2}{|c|}{$\begin{array}{l}\text { Number of Years the Firm Expects } \\
\text { to operate and discount rate }\end{array}$} & $\begin{array}{l}\$ 1,000 \text { per Worker } \\
\text { Special Incentive } \\
\text { Grant }\end{array}$ & $\begin{array}{c}\text { PRIDCO } \\
\text { Construction* }\end{array}$ & $\begin{array}{l}\text { Extra Years Cor- } \\
\text { porate Tax ex- } \\
\text { emption }\end{array}$ & \\
\hline 4 Years & $30 \%$ & $16.5 \%$ & $9.1-20.3 \%$ & 0 & $25.6-36.8 \%$ \\
\hline 4 Years & $6 \%$ & $10.3 \%$ & $5.9-13.1 \%$ & 0 & $16.2-23.4 \%$ \\
\hline 12 Years & $20 \%$ & $8.0 \%$ & $4.4-9.2 \%$ & $1.1-2.3 \% * *$ & $13.5-19.5 \%$ \\
\hline 17 Years & $30 \%$ & $10.8 \%$ & $6.1-12.9 \%$ & $1.3-2.5 \% * * *$ & $18.2-26.2 \%$ \\
\hline 17 Years & $6 \%$ & $3.4 \%$ & $1.9-3.8 \%$ & $6.3-13.5 \% * * *$ & $11.6-20.7 \%$ \\
\hline
\end{tabular}

*Information in Table 7 deflated by $42 \%$ to account for the opportunity cost of capital.

**2 added to 10 Years Exemption for a 12-Year Income Stream.

***7 added to 10 Years Exemption for a 17-Year Income Stream. 
to be recovered by rental payments. For example, if $6 \%$ interest rate is assumed, metropolitan San Juan rents capitalize PRIDCO plants in less than 14 years while rural rents capitalize between $58 \%$ and $89 \%$ of construction costs within 16 years. Nevertheless, if any of the intra-regional incentives attract new firms to the island or induce new expansion in existing rural firms, then new workers are subject to income taxes and the Puerto Rican government indirectly recovers some of its costs. The magnitude of these indirect increases in government revenue remains as a topic for further research.

\section{FOOTNOTES}

1Benjamin Bridges, Jr., "State and Local Inducements for Industry," National Tax Journal, June 1965, p. 191.

${ }^{2}$ Commonwealth of Puerto Rico, Economic Development Administration, Annual Statistical Report of EDA Manufacturing Plants, 1964-65 Edition, San Juan: Economic Development Administration, 1967, Section II-D, Table 19.

3Ibid., Section II-C, Table 16.

${ }^{4}$ Ibid.

5Although Puerto Rico is a Commonwealth associate of the United States, corporate and private residents of the island pay no taxes to the United States Treasury. While corporations from outside the United States are eligible for the Puerto Rican incentives such as the tax exemption, their Puerto Rican profits may (or may not) be taxed by their home country.

6Kenneth Kauffman, "Income Tax Exemption and Economic Development," National Tax Journal, June 1960, pp. 141-62.

${ }^{7}$ United States Treasury Department, Internal Revenue Service, "Bulletin F; Tables of Useful Lives of Depreciable Property," reprinted in 1955 without change from 1942 revised "Bulletin F".

8Edwin Kuh and Richard Schmalensee, "An Introduction to Applied Macro-economics," Working Paper, Alfred Sloan School, Massachusetts Institute of Technology, December 1970, pp. 4A-10. 